DOI https://doi.org/10.30525/978-9934-26-000-1-26

\title{
МЕДІЙНА РЕПРЕЗЕНТАЦІЯ ПАНДЕМІЇ У ФОТОГРАФІЇ
}

\author{
Лисенко Л. I. \\ кандидат наук із соціальних комунікаџій, \\ доцент кафедри журналістики \\ Полтавський національний педагогічний університет \\ імені В. Г. Короленка \\ м. Полтава, Украӥна
}

Одним із найважливіших складників соціальної координації під час пандемії, спричиненої поширенням вірусу COVID-19, є інформаційний - це спонукає розглядати ситуацію, що склалася на глобальному рівні, як колективну інформаційну травму. У спостереженнях за системою комунікаційного механізму пандемії простежується аналогія 3 дослідженням Сергія Мирного про Чорнобиль, де зазначено, що «інформація стала детонатором безпрецедентно потужного вибуху, перетворила аварію на ЧАЕС на Чорнобильську катастрофу» [2].

У мережі поширюються відгуки, пов'язані зі звинуваченням медіа в нагнітанні ситуації довкола пандемії, тиражуванні неправдивих фактів, неправильному опрацюванні кількісних показників і спотворенні їх візуального представлення. Так формується страх, породжений незнанням і посилений інформаційним шумом. Щодо цього Катерина Яковленко зауважує: «Об'єктивно мій страх нічим не підкриплювався, але суб'єктивно знаходив підгрунтя у численних публікаціях в інтернеті» [8]; «паніка довкола вірусу нагніталася через візуальну культуру здебільшого фотографії, передруковані у медіа» [8]. Емпатичний потенціал фотографії зробив іiі пріоритетним комунікаційним інструментом у соціальній рекламі від ЮНІСЕФ та Vandog [3]. За задумом розробників концепції, портрети лікарів, волонтерів, соціальних працівників покликані оживати в історіях про їнні подвиги і спонукати до солідарності, співчуття і допомоги. Знаково, що в повідомленнях про загибель лікаря Івана Венжиновича медіа апелювали до його участі в кампанії («герой із білборда»).

Фотографія у складних соціальних обставинах, як правило, $\epsilon$ основним медійним джерелом означення, фіксації та поширення травматичних досвідів. Більше того, оперуючи універсальною візуальною мовою, вона конструює ці досвіди, а через них оприявлюється сама реальність. Валерій Савчук стверджує: «Визнаючи, що візуальний образ уже не відображає, а сам є реальністю, єдиною, яка доступна людині і дійсно впливає на неї, ми повинні прийняти, що буття образу збігається із буттям як таким» $[5$, с. 8$]$. У віртуальній реальності смисли часто обрамлені в штучно створені образи. Наприклад, зображення 
клітин COVID-19 можуть провокувати відчуття тривоги [6]. Образне унаочнення вірусу є своєрідною спробою візуалізувати невидиму загрозу і в такий спосіб задокументувати іiі. Клітина як символьне уособлення небезпеки - лише одне із множинних візуальних кліше, створених і розтиражованих у медіа.

Будь-яка значуща подія глобального масштабу в колективному сприйнятті вибудовується довкола системи візуальних знаків, найактивніше репрезентованих у фотографіях. Характер рецептивних реакцій на них залежатиме від рівня драматичності соціальних досвідів. На думку Олени Петровської, «нетравматичне взагалі не афіціює чуттєвість і залишається за порогом сприйняття» [4, с. 509]. Сюжети війни, теракту, катастрофи у фотомедійному середовищі стають набором візуальних кліше: кров, вибух, понівечене тіло, зброя, зруйновані будівлі тощо. Ця образна система конструює своєрідну матрицю сприйняття, відтворення події, верифікація інформації в пам'яті. Фотодокументи такої проблематики реально зафіксують події, $є$ серед них і постановні кадри. Ця система знаків-кліше вибудовуються за встановленими алгоритмами. Подієва інтенсивність трагедій передбачає множинність візуалізованих сюжетних варіацій, які представлені, наприклад, у воєнній фоторепортажистиці.

Медійна репрезентації пандемії та спричинених нею загроз за рік сформувала набір своїх візуальних стереотипів: маски (кисневі i медичні), лікарі (зазвичай, у захисному одязі), медична апаратура i приладдя. Через обмеженість доступу до осередків перебігу основних подій (лікарень) і надоперативність новинних оновлень медіа для наочного супроводу текстових повідомлень, як правило, використовують фотографії інформаційних агентств або зі стоків. Така інформація репрезентує абстрактні образи хворих, лікарів, фрагменти з акцентами на стандартному візуальному наборі тощо. Фактично реципієнти самостійно наповнюють ці фото емоційним і сюжетними сенсами в міру активності емпатії, заточеності свідомості на моніторинг критичної ситуації, причетності до події. Наприклад, драматичне (частково спростоване) повідомлення про батька, який помер в одній із районних лікарень, віддавши свій кисень хворому на коронавірус синові, у медіа супроводжувалося саме такими абстрактними фото: пусте лікарняне ліжко, хвора людина на апараті ШВЛ, фрагмент руки чоловіка 3 кисневою маскою. Ця ситуація унаочнює думку Сьюзен Зонтаг, що «образшок і образ-кліше - дві сторони одного й того ж явища» [7, с. 21].

$€$ кілька резонансних фоторепортажів українських і зарубіжних авторів, у яких зафіксована історія пандемії в ії епіцентрах: фоторепортаж «Спаси і сохрани» (Свген Малолєтка), «Великдень у час пандемії» (Данило Павлов), фоторепортаж із Бергано від The New Yourk Times. У проєктах вуличних фотографів репрезентовані історії життя міст під час карантину, а також особистісні переживання, на прикладі фотоісторії «Ізоляція» Тараса Бичка: « ...> мені не хотілося знімати вже звичні 
маркери - людей у масках і рукавичках, соціальну дистанцію - чи щось на кшталт щоденника карантину. Натомість, поки я пропускав цю тему крізь себе (або вона - мене?), в уяві спонтанно виникали й накопичувалися певні образи стану внутрішньої ізоляції» [1]. Усі ці приклади означують процеси соціальної стандартизації нових реалій: хвороба та iii наслідки, карантин, ізоляція тощо. Документальна фотографія мобілізує колективну рефлексію на основі сформованих медіаобразів.

У світі, переповненому цифровою інформацією, фотографія не просто фіксує події, явища, людей, а й наділяти їхнє відкадроване буття смислами. Тема пандемії, вийшовши на перший план медіасвіту, потужно активувала в новинних стрічках візуальний контент, який миттєво проникає в рецептивну систему й відчутно резонує у стандартизованих реакціях медіаспоживачів. Накопичення образів-кліше в популярних стокових фотографіях, доступність приватних світлин із соціальних мереж про жертв хвороби загострює невизначеність комунікаційної політики в тематизованих публікаціях. Драматизм сучасної ситуації з часом отримає всебічне осмислення, але вже тепер актуальна фотографія послідовно й неухильно генерує смислові коди в людській пам'яті.

\section{Лiтература:}

1. Бичко Т. Ізоляція. Reporters. URL: https:/www.reporters.media/ izolyatsiya/ (дата звернення 22.11)

2. Мирний С. Чорнобиль як інфо-травма. Критика. URL: https:// krytyka.com/ua/articles/chornobyl-yak-info-travma (дата звернення 22.11)

3. Національна кампанія солідарності у відповідь на пандемію кризові комунікації від ЮНІСЕФ та Vandog. Sostav.ua. URL: https:// sostav.ua/publication/nats-onalna-kampan-ya-sol-darnost-u-v-dpov-d-napandem-yu-krizov-komun-kats-v-d-yun-85309.html (дата звернення 22.11)

4. Петровская Е. «Какая угодно» фотография. Новые аудиовизуальные технологи: Сборник статей. СПб. : «Дмитрий Буланин», 2011. C. $485-512$

5. Савчук В.В. Философія фотографии. СПб. : Изд-во С.-Петерб. ун-та, 2005. $256 \mathrm{c.}$

6. Севедж. М. Що Covid робить 3 нашою психікою. А як це було після аварії на ЧАЕC? ВBC News. Україна. URL: https://www.bbc.com/ ukrainian/vert-cap-54839461 at custom4=899901D2-2BFA-11EB-96C2977C96E8478F\&at_campaign $=\overline{6} 4 \&$ at_custom $1=\% 5$ Bpost + type $\% 5$ D\&at_cu stom $2=$ facebook_page\&at_custom $3=\overline{\mathrm{BBC}}+\mathrm{News}+\mathrm{Ukraine} \&$ at_medium $=\bar{c}$ cus tom7\&fbclid=IwAR1dF1X XmX90dM19Sx46Jkw_Luifpkf94GyQNaBAdMx oSC-2Lc3dur2yC2k (дата звернення 22.11)

7. Сонтаг С. Смотрим на чужие страдания. М. : ООО «Ад Маргинем Пресс», 2014. 96 с.

8. Яковленко К. Пандемічна тривога та нова ритуальність. YourArt. URL: https://supportyourart.com/zapalennia/pandemic-tryvoga-mova-rytualnist (дата звернення 22.11) 